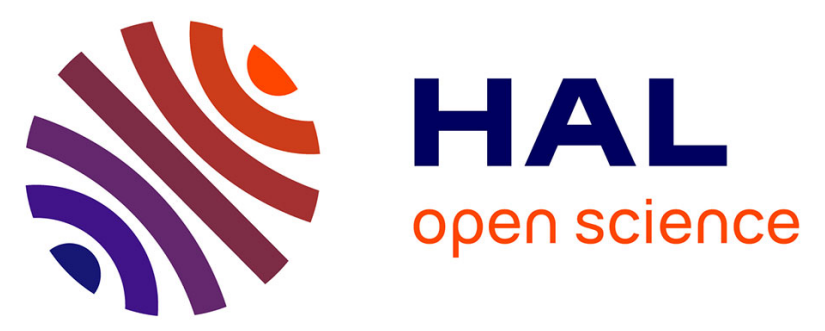

\title{
Enhanced method and tools for child thoracic and abdominal compliance assessment by clinical treatments observation
}

\author{
François Bermond, Jacques Bergeau, François Alonzo, Clément Goubel, \\ Karine Bruyere-Garnier, Patrick Joffrin, Bernard Cossalter, Jean-Pierre \\ Verriest
}

\section{To cite this version:}

François Bermond, Jacques Bergeau, François Alonzo, Clément Goubel, Karine Bruyere-Garnier, et al.. Enhanced method and tools for child thoracic and abdominal compliance assessment by clinical treatments observation. The 5th World Congress of Biomechanics, Jul 2006, MUNICH, Germany. pp.S155，10.1016/S0021-9290(06)83528-1 . hal-02103865

\section{HAL Id: hal-02103865 \\ https://hal.science/hal-02103865}

Submitted on 18 Apr 2019

HAL is a multi-disciplinary open access archive for the deposit and dissemination of scientific research documents, whether they are published or not. The documents may come from teaching and research institutions in France or abroad, or from public or private research centers.
L'archive ouverte pluridisciplinaire HAL, est destinée au dépôt et à la diffusion de documents scientifiques de niveau recherche, publiés ou non, émanant des établissements d'enseignement et de recherche français ou étrangers, des laboratoires publics ou privés. 
BERMOND, François, BERGEAU, Jacques, ALONZO, François, GOUBEL, Clément, BRUYERE-GARNIER, Karine, JOFFRIN, Patrick, COSSALTER, Bernard, VERRIEST, Jean-Pierre, 2006, Enhanced method and tools for child thoracic and abdominal compliance assessment by clinical treatments observation, Journal of Biomechanics, The 5th World Congress of Biomechanics, MUNICH, ALLEMAGNE, 2006-07-29, 39, supp1, Elsevier, S155, DOI: $10.1016 / \mathrm{S} 0021-9290(06) 83528-1$

Enhanced method and tools for child thoracic and abdominal compliance assessment by clinical treatments observation

Francois Bermond ${ }^{\mathrm{a}}$, Jacques Bergeau ${ }^{\mathrm{b}}$, Francois Alonzo ${ }^{\mathrm{a}}$, Clément Goubel $^{\mathrm{a}}$, Karine Bruyère ${ }^{\mathrm{a}}$, Patrick Joffrin ${ }^{\mathrm{a}}$, Bernard Cossalter ${ }^{\mathrm{b}}$, Jean-Pierre Verriest ${ }^{\mathrm{a}}$

a INRETS - LBMC, 25 avenue Francois Mitterrand, F 69675 Bron cedex, France b Université Joseph Fourier Grenoble 1, Ecole de Kinésithérapie du Centre Hospitalier Universitaire de Grenoble, 19 Avenue de Kimberley, BP 158, F 38431 Echirolles cedex, France * Now at LIER S.A., D29 Route de Crémieu, BP 352, F 69125 Lyon Saint Exupéry Aéroport, France

The aim of our study is to obtain realistic values of child thoracic and abdominal compliance. The thoracic and abdominal compliance represents the capacity of deformation under the effect of mechanical solicitation. The dynamic response of the thoracic and abdominal segment is essential because it is one of the main parameters of the whole restraint mechanism in a car child restrain device.

We propose to quantify the thoracic and abdominal compliance in observing thoracic and abdominal manipulations carried out within the framework of usual physiotherapic treatments. All the measurements will be done without any contact with the children. Only the displacement of the upper face of the practitioner's hand and the applied load will be recorded. A three dimensional analysis will be performed to reconstruct the displacement.

Furthermore the value distribution as a function of several variables such as age, sex and anthropometrics will be taken into account.

This research will be used to improve the bio-fidelity of the chest and abdomen of child dummies in order to better evaluate the thoracic and abdominal injury risk for children involved in road accidents.

This more realistic prediction of the child injury severity in the case of a collision may have a positive effect on road safety. Indeed, those new data will allow a better evaluation of the current and future restraint systems, for example in the frame of vehicle homologation test procedures as the EuroNCAP. 